\title{
PROGRAM PENGABDIAN MASYARAKAT: SISTEM INFORMASI ADMINISTRASI PERJALANAN DINAS PADA KANTOR GUBERNUR PROVINSI KALIMANTAN TIMUR DI BIRO UMUM
}

\author{
Azahari $^{1)}$, Reza Andrea ${ }^{2)}$, Siti Lailiyah ${ }^{3),}$ dan Fahmi Fitnanda ${ }^{3)}$ \\ ${ }^{1,2,3}$ Teknik Informatika, STMIK Widya Cipta Dharma \\ ${ }^{4}$ Sistem Informasi, STMIK Widya Cipta Dharma \\ Jl. M. Yamin No.25, Samarinda, 75123 \\ E-mail : azahari@wicida.ac.id ${ }^{1)}$,reza@wicida.ac.id ${ }^{2}$, lailiyah@wicida.ac.id ${ }^{3)}$, fachmifitnanda@gmail.com ${ }^{4)}$
}

\begin{abstract}
ABSTRAK
Program pengabdian masyarakat dilakukan dengan membuat sebuah sistem informasi administrasi perjalanan dinas berbasis website yang dapat membantu Biro Umum dalam melakukan proses pembuatan surat perintah perjalanan dinas, laporan dan memberikan informasi sisa dana anggaran pada perjalanan dinas. Program pengabdian masyarakat ini dilakukan di Biro Umum Sekretariat Daerah Provinsi Kalimantan Timur. Metode pengumpulan data yang digunakan yaitu dengan wawancara dengan mengajukan pertanyaan - pertanyaan yang berkaitan dengan administrasi perjalanan dinas, tata cara melakukan pembuatan perjalanan dinas dan bentuk output dari surat perintah perjalanan dinas. Dalam program pengabdian masyarakat ini tahapan pengembangan sistem yang digunakan yaitu waterfall model dengan perangkat lunak pendukung yang digunakan adalah Brackets, PhpMyadmin. Adapun hasil akhir dari program pengabdian masyarakat ini yakni berupa sistem informasi berbasis website yang dapat menyajikan informasi, data, pembuatan yang lebih mudah digunakan dan lebih cepat. Sistem Informasi Administrasi Perjalanan Dinas sebagai media dalam pengadministrasian yang dapat mengolah data secara mudah, efektif dan efisien
\end{abstract}

Kata Kunci: Sistem Informasi, Perjalanan Dinas, Administrasi, Biro Umum, Website

\section{PENDAHULUAN}

Pemerintahan dibentuk dengan maksud untuk membangun peradaban dan menjaga sistem ketertiban sosial sehingga masyarakat bisa menjalani kehidupan secara wajar dalam konteks kehidupan bernegara. Penyelenggaraan pemerintahan yang baik adalah landasan bagi penyusunan dan penerapan kebijakan negara yang demokratis dalam era globalisasi (Yuniarto, 2013)

Fenomena demokrasi ditandai dengan menguatnya kontrol masyarakat terhadap penyelenggaraan pemerintahan, sementara fenomena globalisasi ditandai dengan saling ketergantungan antara bangsa, terutama dalam pengelolaan sumber-sumber daya ekonomi dan aktivitas dunia usaha (Heryanto,2014). Penggunaan komputer pada instansi pemerintah saat ini juga semakin meningkat mengikuti zaman yang serba cangging diikuti dengan penerapan sistem informasi dalam pekerjaan sehari-hari (Sutabri, 2012). Tidak hanya organisasi saja yang membutuhkan sistem informasi melainkan seluruh aspek kehidupan (Basrie \& Yusnita, 2018) termasuk Biro Umum Sekretariat Daerah Provinsi Kalimantan Timur didalam pengelolaan pelaporan rekapitulasi pelaporan perjalanan dinas. Proses rekapitulasi perjalanan dinas pegawai tersebut membutuhkan infromasi yang selalu up to date dan laporan-laporan yang akurat dan tepat waktu.
Oleh karena itu dibutuhkan sebuah sistem informasi yang menggunakan komputer untuk mengolah data perjalanan dinas serta rekapitulasinya. Saat ini pada proses laporan rekapitulasi perjalanan dinas masih dilakukan secara manual dimana setiap pembuatan surat tugas dan kuitansi pembayaran perjalanan dinas masih menggunakan Microsoft Excel, sehingga pelaporan dan pembuatan surat tugas tidak bisa dikerjakan secara cepat, mudah dan kepala bagian cukup kesulitan untuk melihat pegawai yang telah melakukan perjalanan dinas. Dengan adanya sistem yang terkomputerisasi dapat mempermudah dan mempercepat proses pembuatan surat tugas dan rekapitulasi perjalanan dinas serta dapat mengurangi tingkat kesalahan dalam mengetik sebuah nominal.

Berdasarkan permasalahan diatas, keberadaan Sistem Informasi Administrasi Perjalanan Dinas Pada Kantor Gubernur Provinsi Kalimantan Timur Di Biro Umum Berbasis Web dapat membantu dalam pembuatan surat tugas dan pelaporan perjalanan dinas secara online sehingga pekerjaan dapat berjalan dengan cepat, tepat dan akurat serta metode sistem ini bisa menggantikan sistem yang berjalan saat ini.

\section{RUANG LINGKUP PROGRAM PENGABDIAN}

Kegiatan pengabdian masyarakat difokuskan pada: 
1. Pembuatan Surat Perintah Perjalanan Dinas dan Rincian Biaya Perjalanan Dinas.

2. Pembuatan SPPD berdasarkan dari data pegawai, uang harian perjalanan dinas dan DPA.

3. Pembuatan Laporan Perjalanan Dinas, Perincian Biaya Perjalanan Dinas.

\section{TAHAPAN KEGIATAY}

Model Air Terjun (waterfall), sering juga disebut model sekuensial linier (sequential linier) atau alur hidup klasik (Classic Life Cycle) (Nugroho, 2009)). Model air terjun menyediakan pendekatan alur hidup perangkat lunak secara sekuensial atau terurut dimulai dari Analisis, design, pengkodean, pengujian, implementasi atau pemeliharaan (Kusnandar, 2016).

Program pengabdian ini dilaksanakan melalui beberapa tahapan pengembangan waterfall sebagai berikut :

1. Tahapan Analisis, tahapan ini bertujuan untuk memberikan gambaran tentang sistem yang diusulkan meliputi analisis data, analisis kebutuhan, dan analisis teknologi. Tahapan pengumpulan data menggunakan cara pengamatan langsung, wawancara dan studi pustaka.

2. Tahapan Perancangan (design), tahapan ini bertujuan untuk merancang sebuah sistem atau design tampilan pada sistem menggunakan UML(Unified Modeling Languange).

3. Tahapan Penulisan Program (Pengkodean), tahapan ini bertujuan untuk menerjemahkan design dalam bahasa yang bisa dikenali oleh komputer. Bahasa pemrograman yang dipakai yaitu PHP dan database yang digunakan yaitu MySQL.

4. Tahapan Pengujian, Tahapan ini berfungsi sebagai penguji pada sistem yang akan dibangun.

5. Tahapan Implementasi atau Maintenance, tahapan ini berfungsi sebagai penerapan atau pemeliharaan program secara berkala atau rutin

\section{RANCANGAN SISTEM}

Dari hasil analisis sistem maka didapatkan sebuah rancangan untuk desain dari sistem yang akan dibangun. Untuk merancang sebuah sistem digunakan alat bantu pengembangan sistem menggunakan UML dan Site map.

\subsection{UML (Unified Modeling Language)}

$U M L$ adalah bahasa pemodelan untuk sistem atau perangkat lunak yang berparadigma berorientasi objek (Jogiyanto, 2010). Pemodelan (modeling) sesungguhnya digunakan untuk penyederhanaan permasalahanpermasalahan yang kompleks sedemikian rupa sehingga lebih mudah dipelajari dan dipahami. UML adalah sebuah bahasa yang menjadi standart untuk visualisasi, merancang dan mendokumentasikan sistem piranti lunak.

\subsubsection{Use Case Diagram}

Untuk mengenal proses dari suatu sistem digunakan diagram use case (gambar 1). Dengan diagram use case ini dapat diketahui proses yang terjadi pada aplikasi. Pada gambar 1 dapat dilihat bahwa untuk mengakses website ada 3 level yaitu Admin, User dan Super User. Peran utama dalam sistem ini yaitu level admin yakni dapat menginput, menghapus dan mengubah data perjalanan dinas. Pada level user dan Super User hanya dapat melihat tanpa merubah maupun menghapus data. Penginputan data dapat dilakukan melalui menu halaman Forms.
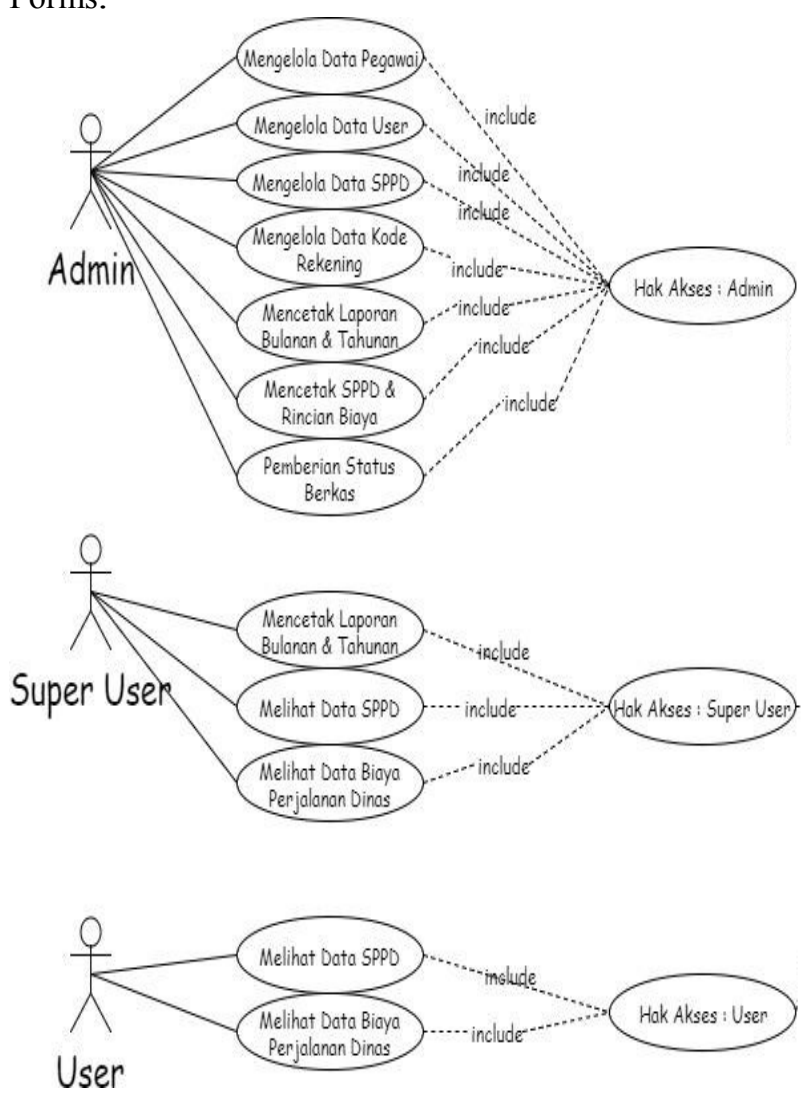

Gambar 1. Use Case Diagram

\subsubsection{Activity Diagram}

Diagram Hak Akses Admin pada gambar 2 dapat dilihat alur aktifitas yang terjadi saat mengakses halaman menggunakan hak akses level admin. Admin memilih "Form Kode Rekening" pada menu navigasi yang telah disediakan. Saat memilih Form Kode Rekening, maka sistem akan langsung menampilkan beberapa inputan yang harus di isi kedalam form tersebut. 


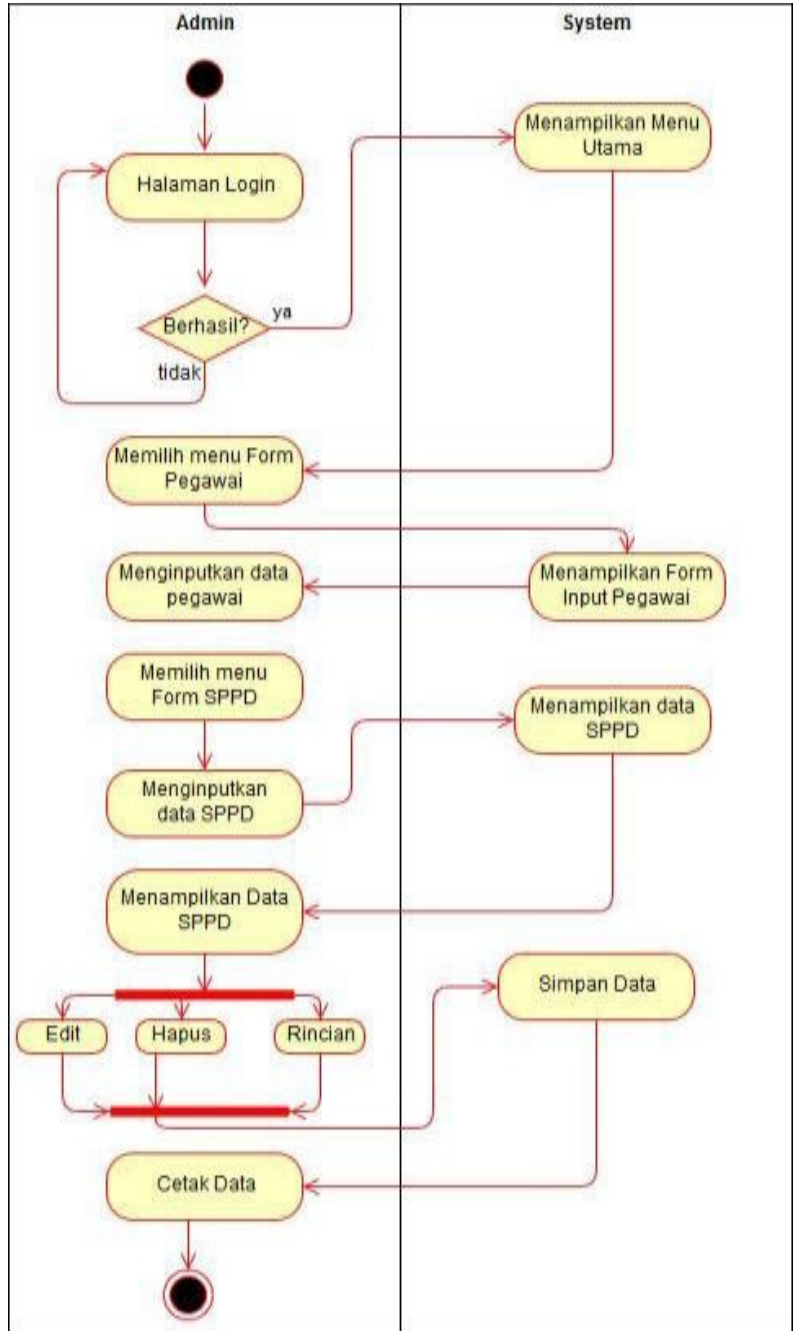

Gambar 2 Activity Diagram Hak Akses Admin

Peran utama dalam sistem ini yaitu level admin yakni dapat menginput, menghapus dan mengubah data perjalanan dinas. Untuk level user dan Super User hanya dapat melihat tanpa merubah maupun menghapus data. Penginputan data dapat dilakukan melalui menu halaman Forms.

Activity diagram hak akses super user pada gambar 3 dapat dilihat alur aktifitas yang terjadi saat mengakses halaman menggunakan hak akses level super user. Hak akses super user hanya dapat melihat data dan mencetak laporan perjalanan dinas dalam daerah maupun luar daerah. Saat berhasil login, halaman utama akan menampilkan kondisi penggunaan biaya perjalanan dinas, sisa dana perjalanan dinas dan grafik perjalanan dinas tiap bulannya.

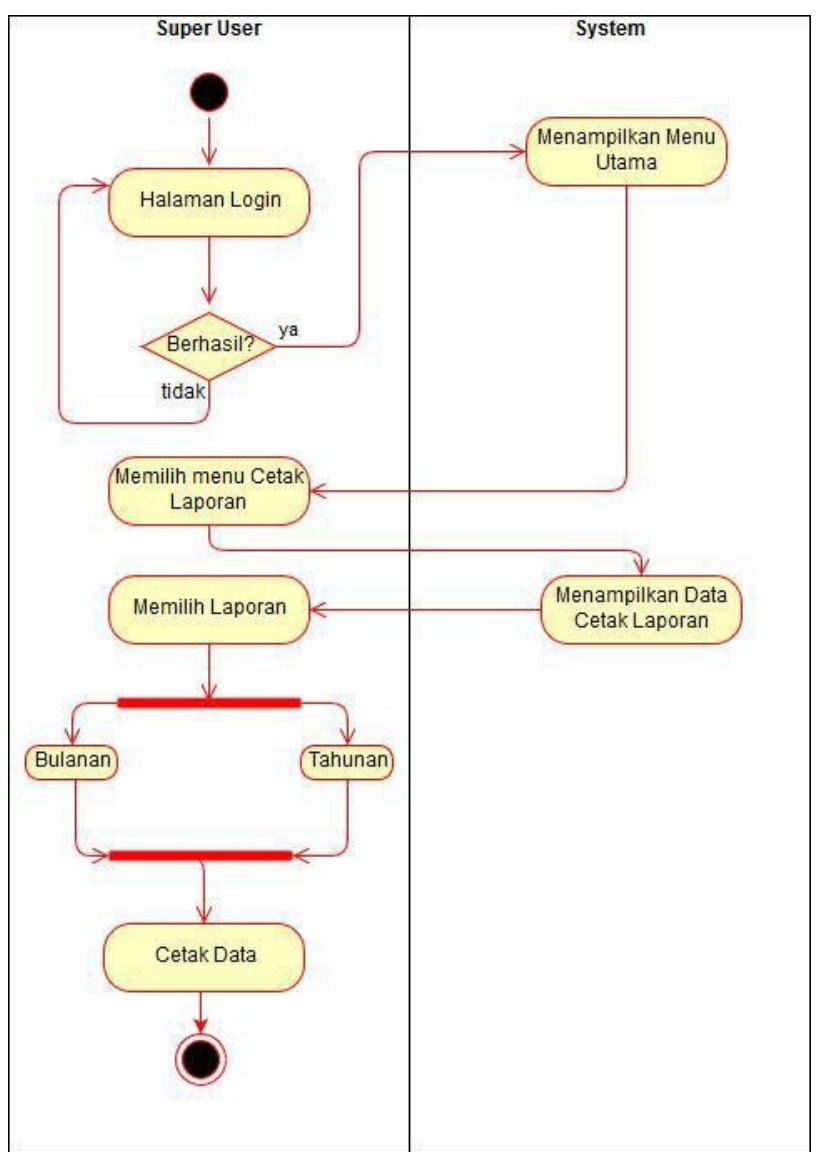

Gambar 3. Activity Diagram Hak Akses Super User

Pada gambar 3 dapat dilihat proses membuat atau mencetak laporan perjalanan dinas bulanan maupun tahunan. Pada menu cetak laporan terdapat beberapa pilihan diantaranya cetak laporan bulanan dan tahunan dalam daerah, cetak laporan bulanan dan tahunan luar daerah dan serta cetak laporan dalam dan luar daerah bulanan maupun tahunan.

Activity diagram hak akses user pada gambar 4 dapat dilihat alur aktifitas yang terjadi saat mengakses halaman menggunakan hak akses level user. Hak akses user hanya dapat melihat data perjalanan dinas. Saat berhasil login, halaman utama akan menampilkan kondisi penggunaan biaya perjalanan dinas, sisa dana perjalanan dinas dan grafik data perjalanan dinas tiap bulannya. Hak akses user dapat melihat data - data perjalanan dinas dan dapat mengetahui status dari berkas yang telah diserahkan. 


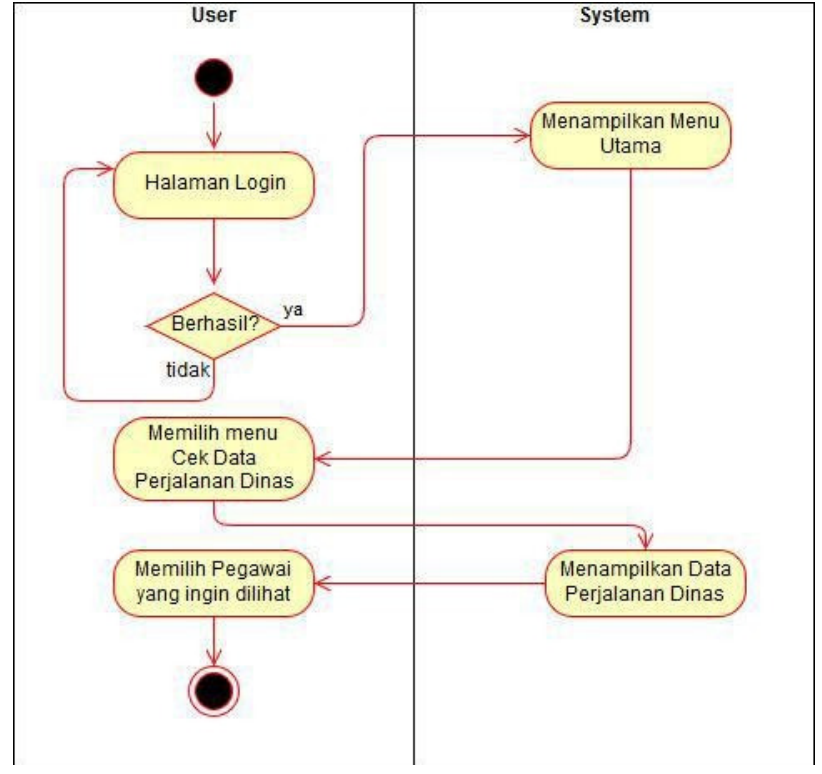

Gambar 4. Activity Diagram Hak Akses User

\subsubsection{Class Diagram}

Pada gambar 5 menujukan relasi antar tabel dan view. Pada relasi ini tabel SPPD memberikan relasi terhadap beberapa tabel diantaranya tabel rincian_pesawat, rincian_darat, rincian_lumpsum, rincian_penginapan, dan tabel total lalu di berikan tabel tambahan yaitu berupa view_rincian yang berfungsi sebagai penerima data - data yang dikirimkan lewat relasi yang sudah dibangun.

Pada tabel pegawai berfungsi sebagai tempat penyimpanan data - data pegawai dan akan di relasikan atau dihubungkan ke table SPPD. Pada view_rincian tersebut berfungsi sebagai tempat mencetak rincian biaya per nomor SPPD.

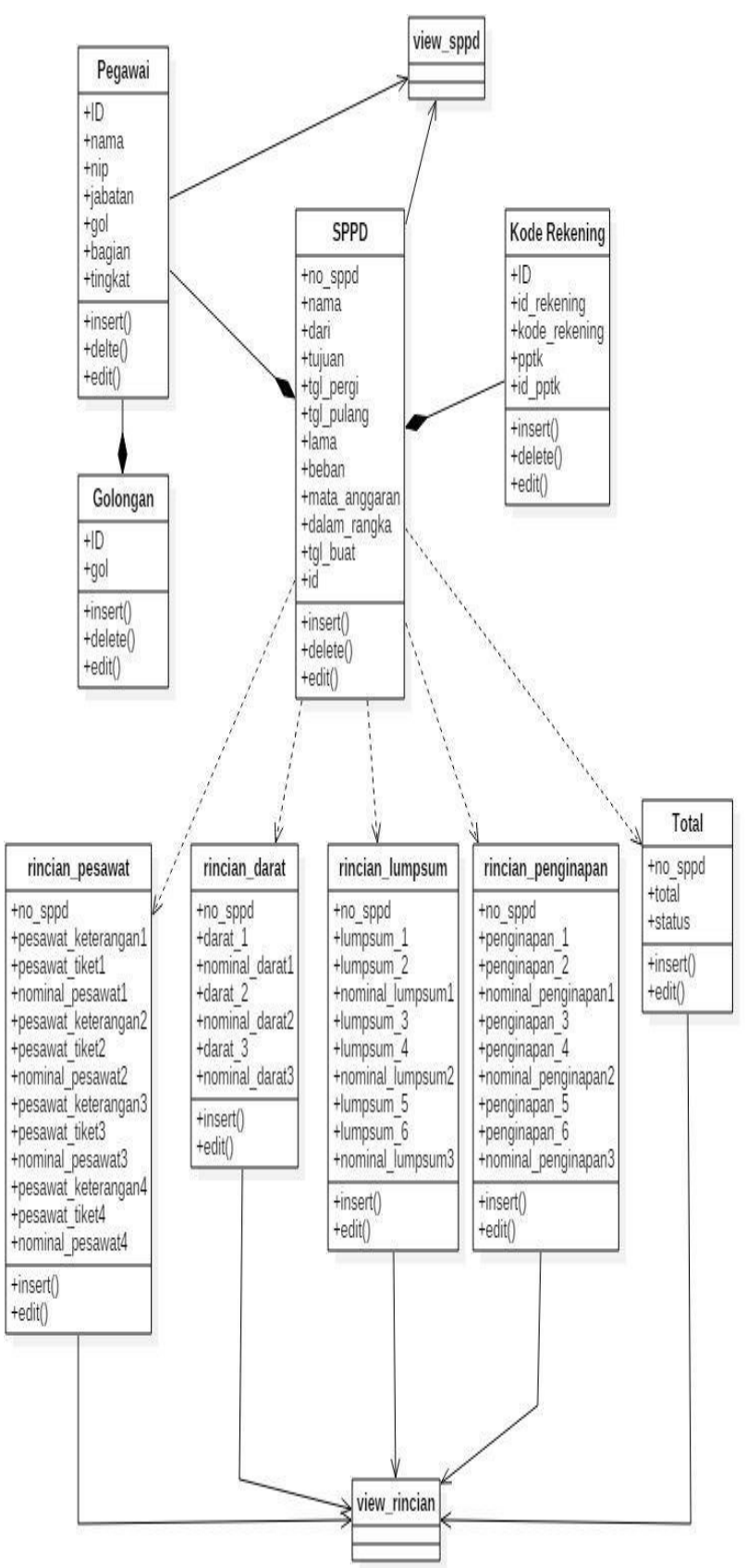

Gambar 5. Class Diagram 


\subsection{Site Map}

Dalam menjelaskan struktur halaman website maka dibuatkan sebuah sitemap untuk lebih memahami struktur dari halaman website itu sendiri.

1. Site Map Admin

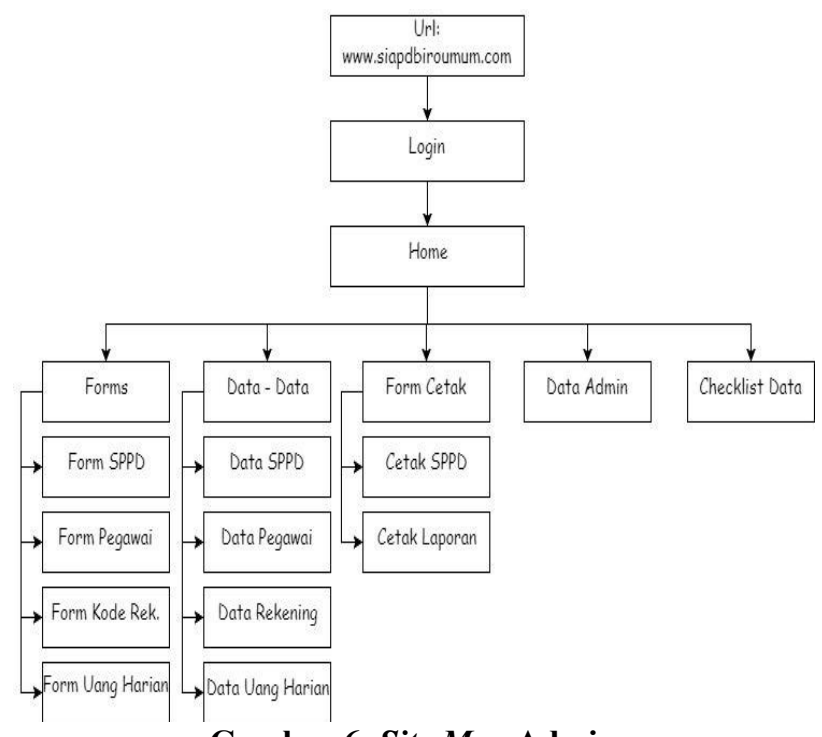

Gambar 6. Site Map Admin

Site map gambar 6 menjelaskan bagaimana struktur website jika setelah login atau masuk kedalam website dengan menggunakan hak akases Administrator atau Admin. Pada site map ini terdapat beberapa halaman utama yaitu Forms, Data - Data, Form Cetak, Data Admin dan Checklist Data.

2. Site Map Super User

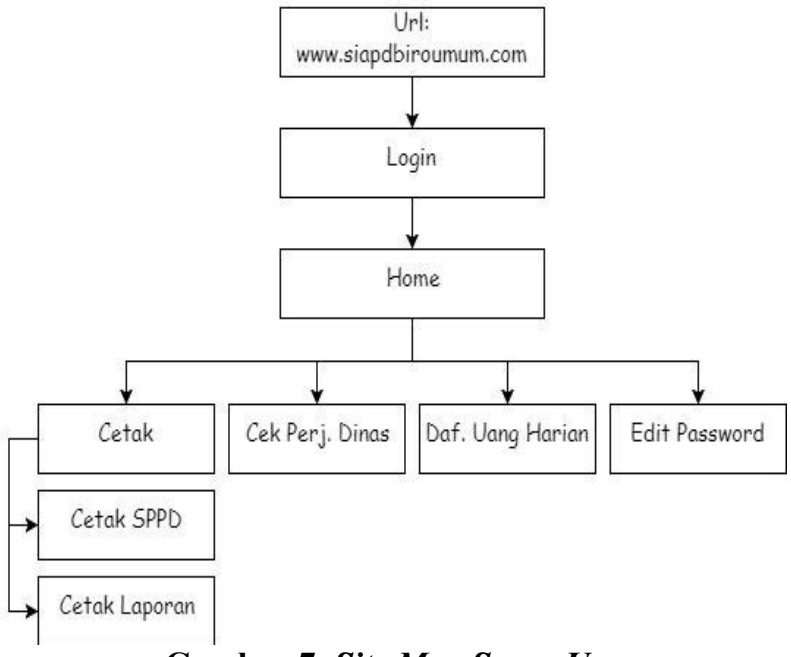

Gambar 7. Site Map Super User

Site map gambar 7 ini menjelaskan bagaimana struktur website jika setelah login atau masuk kedalam website dengan menggunakan hak akses Super User. Pada site map ini terdapat beberapa halaman utama yaitu Cetak, Cek Perjalanan Dinas, Daftar Uang Harian dan Edit Password, Checklist Data.
3. Site Map Common User

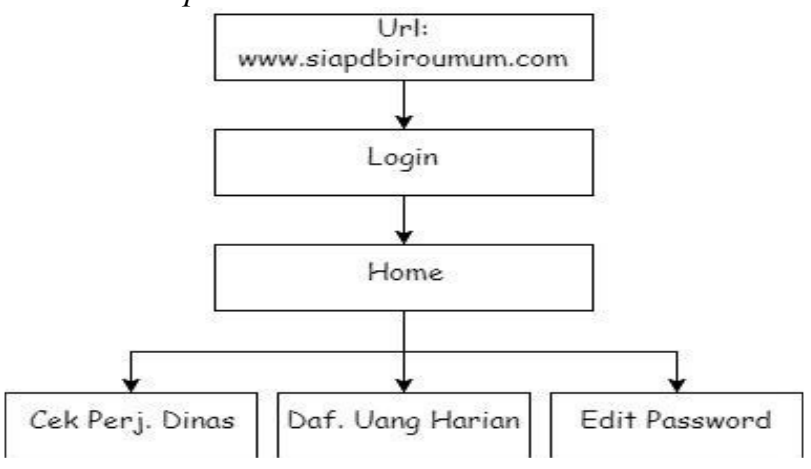

Gambar 8. Site Map Common User

Site map gambar 8 , menjelaskan bagaimana struktur website jika setelah login atau masuk kedalam website dengan menggunakan akun user biasa. Pada site map ini terdapat beberapa halaman utama yaitu Cek Perjalanan Dinas, Daftar Uang Harian dan Edit Password.

\section{IMPLEMENTASI KEGIATAN}

Implementasi program merupakan kelanjutan dari tahap perancangan sehingga sebuah sistem yang nyata dan bisa digunakan seperti menbuat desain Form Sistem

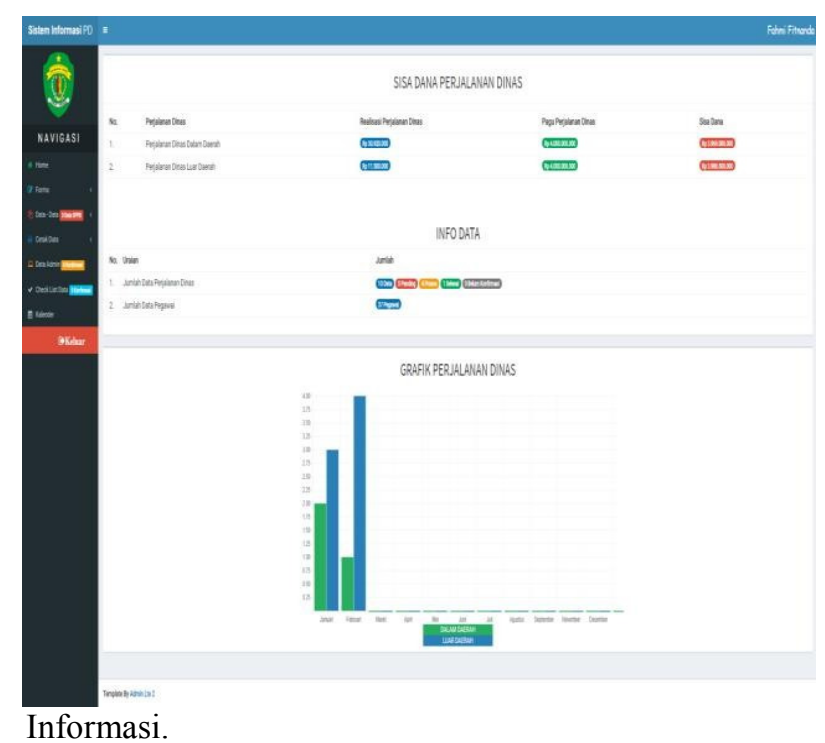

Gambar 9. Halaman Home

Pada halaman home (gambar 9) ini merupakan halaman utama pada Sistem Informasi Administrasi Perjalanan Dinas ini. Pada Halaman utama terdapat informasi - informasi tentang perjalanan dinas. Informasi yang ditampilkan berupa data - data dan grafik batang perjalanan dinas bulanan. Pada menu home terdapat beberapa navigasi menu dan sub menu. 


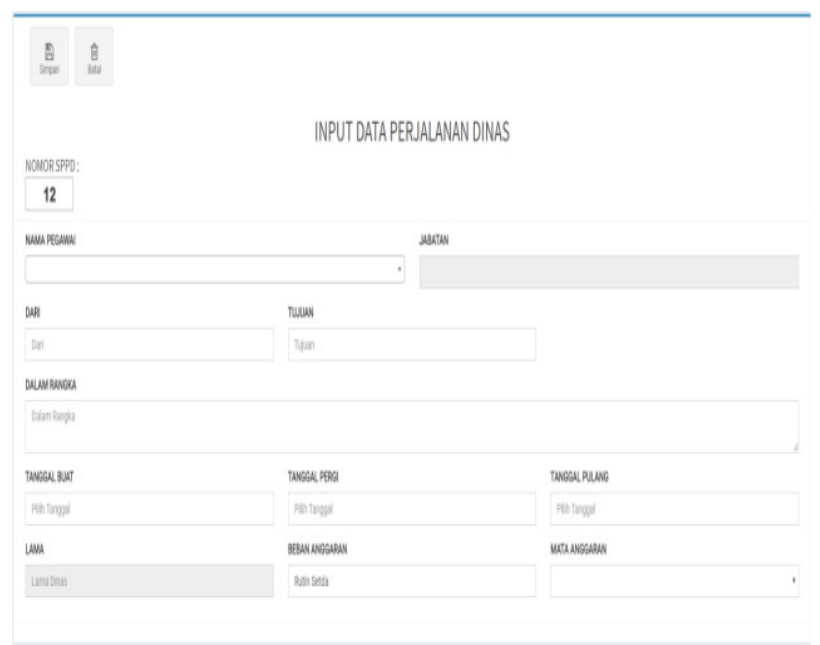

Gambar 10. Halaman Form SPPD

Pada halaman ini (gambar 10) berfungsi sebagai tempat pembuatan surat perintah perjalanan dinas (SPPD). Form SPPD digunakan saat nota dinas persetujuan diterima. Data dari nota dinas persetujuan akan dimasukan kedalam form SPPD untuk dilakukan pencetakan surat perintah perjalanan dinas. Pada menu ini dapat mengisikan nama di kolom inputan nama pegawai dan dapat dicari dengan cara menuliskan nama dan memilih sesuai dengan pilihan. Pada kolom dari dan tujuan dapat mengisikan tempat kedudukan dan tempat tujuan perjalanan dinas.

Pada kolom tanggal buat, tanggal pergi, tanggal puang dapat di isikan dengan cara memilih tanggal buat surat, tanggal pergi dinas dan tanggal pulang dinas dan akan diakumulasikan di kolom lama secara otomatis. Pada kolom beban anggaran dan mata anggaran dapat di isikan sesuai dengan aturan dari DPA (Dana Pagu Anggaran) yang berlaku.

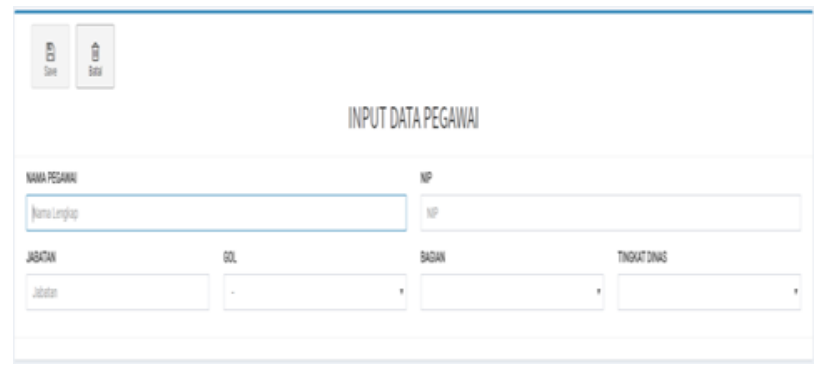

Gambar 11. Halaman Form Pegawai

Pada halaman form pegawai (gambar 11) berfungsi sebagai tempat memasukan data pegawai kedalam database. Penginputan dilakukan dengan cara mengisi sesuai dengan yang tertera di dalam form. Pada menu ini dapat mengisikan data - data pegawai yang belum masuk ke dalam sistem administrasi perjalanan dinas ini. Pada kolom nama pegawai, nip, jabatan dapat mengisikan sesuai dengan nota dinas persetujuan atau sesuai absen yang ada di Biro Umum. Pencarian berdasarkan nama lengkap pegawai dan akan menampilkan NIP secara otomatis. Pada kolom bagian dan tingkat perjalanan dinas dapat memilih dan disesuaikan dengan peraturan perjalanan dinas yang berlaku.

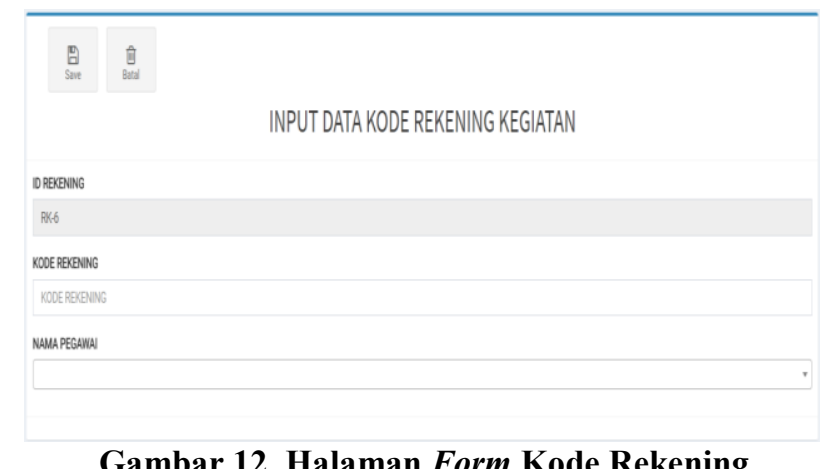

\section{Gambar 12. Halaman Form Kode Rekening}

Gambar 12 adalah halaman yang berfungsi sebagai tempat memasukan data kode rekening kegiatan kedalam database. Penginputan dilakukan dengan cara mengisi sesuai dengan yang tertera di dalam form. Pada menu ini dapat mengisikan kode rekening kegiatan dan nama pptk (Pejabat Pelaksana Teknis Kegiatan) pada kolom nama pegawai sesuai dengan DPA (Dana Pagu Anggaran).

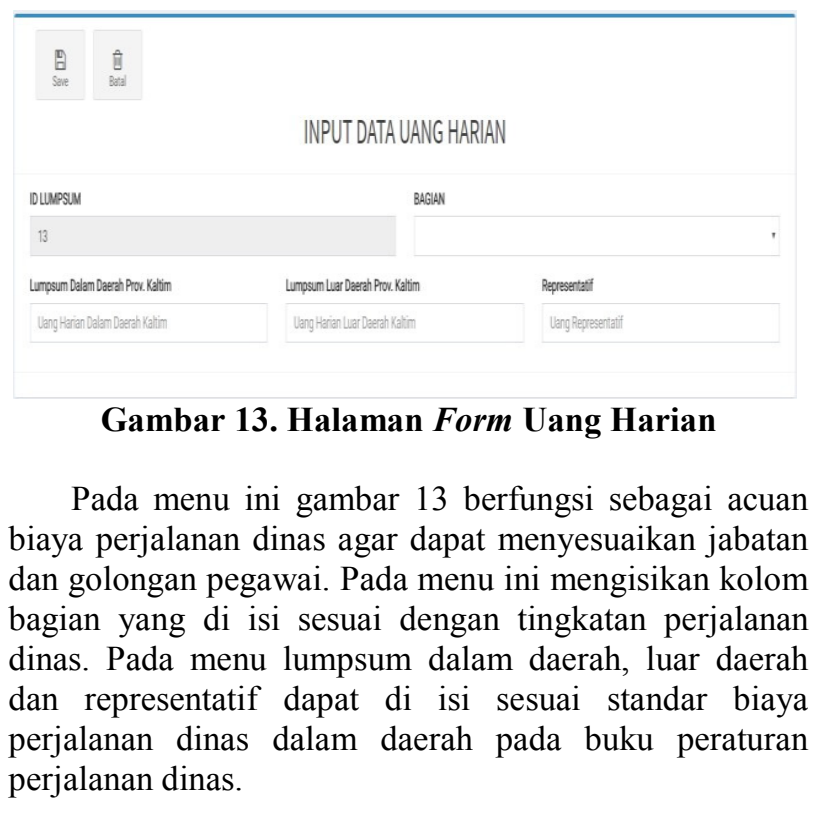




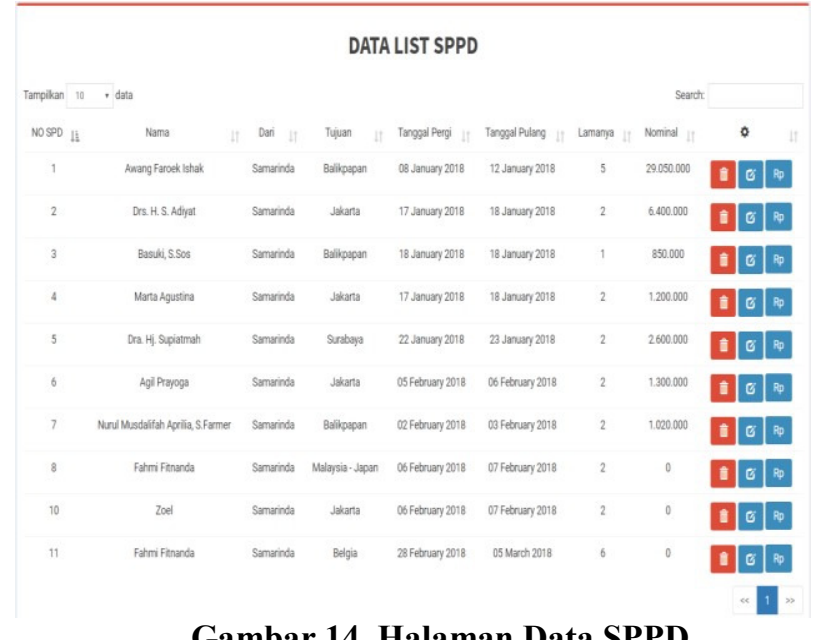

Gambar 14. Halaman Data SPPD

Pada halaman gambar 14, berfungsi menampilkan data - data yang telah di input di form SPPD. Halaman ini dapat mengubah, menghapus dan menambah atau mengedit rincian biaya dengan menekan tombol "Rp". Pada tombol hapus atau tombol warna merah dapat menghapus data. Pada tombol biru bagian tengah berfungsi sebagai tempat mengubah data SPPD.

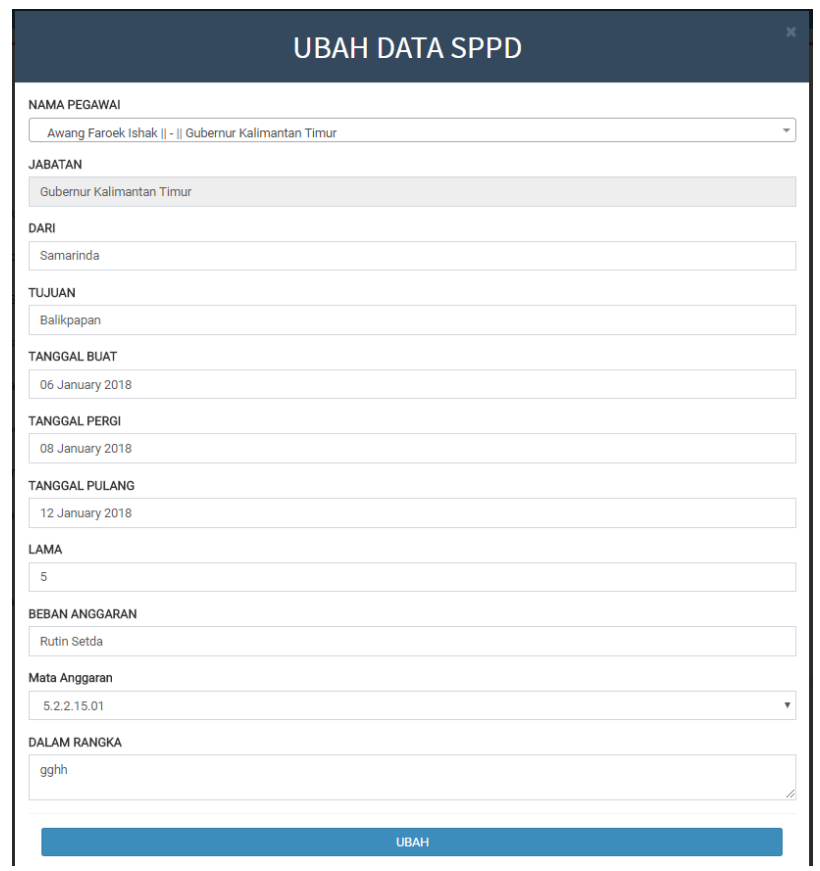

Gambar 15. Halaman Ubah Data SPPD

Pada menu berfungsi sebagai tempat mengubah data SPPD (lihat gambar 15). Pada menu ini dapat mengubah nama pegawai, tempat kedudukan, tempat tujuan, tanggal buat, tanggal pergi, tanggal kembali, beban anggaran, mata anggaran dan maksud atau dalam rangka kegiatan perjalanan dinas.

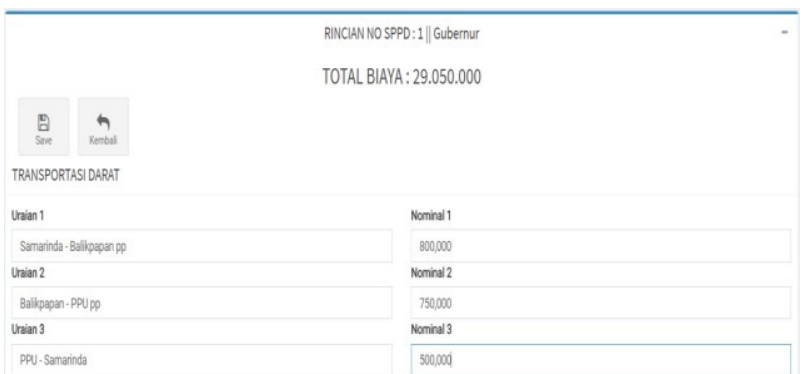

Gambar 16. Halaman Rincian Biaya Transportasi Darat

Pada halaman (gambar 16) ini berfungsi sebagai tempat menginputkan biaya perjalanan dinas untuk transportasi darat. Terdapat 3 (tiga) baris sebelah kiri berfungsi sebagai uraian dari kwitansi transportasi dan 3 (tiga) baris sebelah kanan berfungsi sebagai nominal dari kwitansi transportasi.

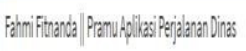 \\ Tarplitan in, wath Seare

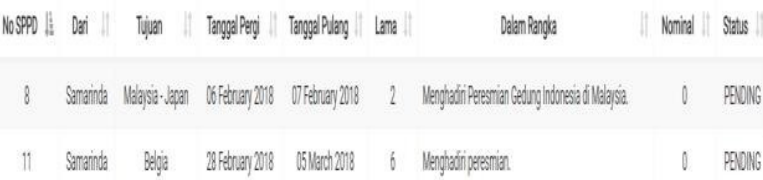 \\ Gambar 17. Halaman Info Data Pegawai}

Pada halaman gambar 17, berfungsi sebagai tempat melihat data pegawai secara individu. Pada halaman ini dapat menampilkan pegawai yang telah melakukan perjalanan dinas dan dapat melihat status berkas.

\begin{tabular}{|c|c|c|c|c|c|c|c|c|}
\hline \multicolumn{9}{|c|}{ DATA REKENING } \\
\hline \multicolumn{3}{|c|}{ Tarplikan 10 , desta } & \multirow[b]{2}{*}{ KOOERERBNG } & & \multicolumn{4}{|c|}{ Serct } \\
\hline No II & DREEBNG & & & & PPTK & it & Q & \\
\hline 1 & R*I & & 5221501 & & Dra Hispiementh & & 10 & \\
\hline 2 & R*2 & & 5221502 & & Drath siputumb & & it $c$ & \\
\hline 3 & AK. & & 4014010311.025221501 & & H. Susuma Sos & & i & \\
\hline 4 & PK4 & & 401.401 .0311 .0252221502 & & H. Susuma SSos & & 00 & \\
\hline 5 & PR.5 & & 5999.01 & & Fodmin frinante & & t & \\
\hline
\end{tabular}

Gambar 18. Halaman Data Rekening

Pada halaman data rekening (gambar 18) menampilkan data - data dari rekening yang telah di input di Form Kode Rekening. Pada halaman ini dapat mengubah dan menghapus data. Pada menu ini terdapat dua tombol yaitu merah dan biru. Pada tombol merah 
berfungsi untuk menghapus data kode rekening dan tombol biru dapat mengubah data kode rekening.

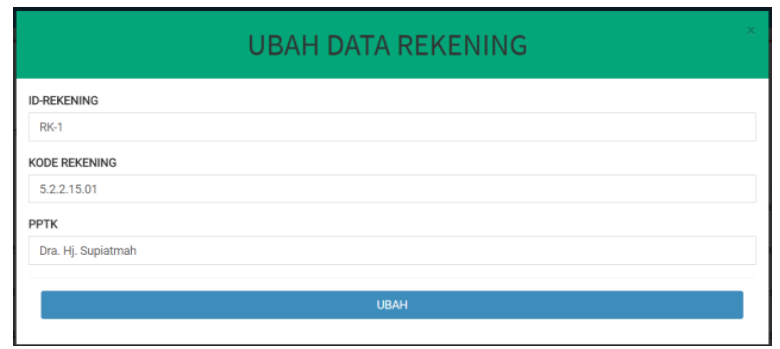

Gambar 19. Halaman Ubah Data Rekening

Pada halaman di gambar 19, berfungsi sebagai tempat mengubah data rekening perjalanan dinas atau kegiatan perjalanan dinas. Pada kolom PPTK mengisikan nama dari pejabat yang bertanggung jawab atas kegiatan atau kode rekening sesuai pada DPA (Dana Pagu Anggaran) yang ada.

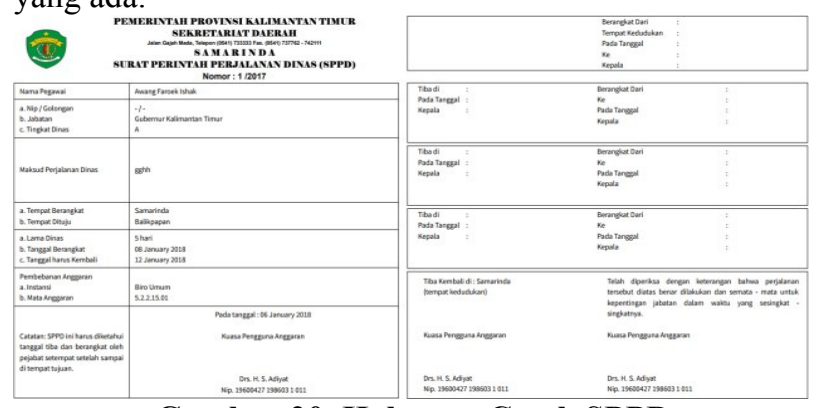

Gambar 20. Halaman Cetak SPPD

Pada halaman ini dapat dilihat tampilan saat mencetak Surat Perintah Perjalanan Dinas (SPPD) lihat gambar 20), berfungsi sebagai bukti dan surat melakukan perjalanan dinas.

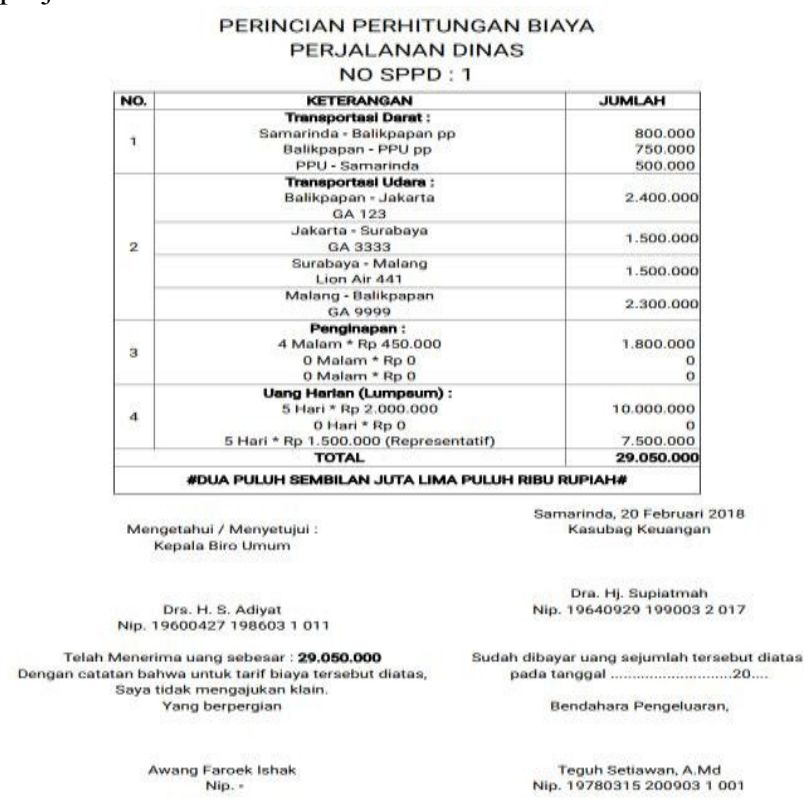

Gambar 21. Halaman Cetak Rincian Biaya
Gambar 21 menampilkan halaman yang dapat memperlihatkan rincian biaya perjalanan dinas, terlihat total keseluruhan pada 1 pegawai saat melakukan perjalanan dinas.

\section{KESIMPULAN}

Berdasarkan uraian diatas, maka kesimpulan dari pogram pengabdian masyarakat ini yaitu, telah dibangunnya Sistem Informasi Administrasi Perjalanan Dinas Pada Kantor Gubernur Provinsi Kalimantan Timur di Biro Umum dapat menyimpan data yang lebih aman, mudah dan dapat diakses melalui jaringan internet.

Dengan sistem ini dapat memberikan kemudahan dalam pembuatan laporan perjalanan dinas bulanan maupun tahunan, serta dapat mencetak surat perjalanan dinas dengan mudah. Sistem Informasi Administrasi Perjalanan Dinas Pada Kantor Gubernur Provinsi Kalimantan Timur di Biro Umum dengan menggunakan bahasa pemrograman html, php dan css dapat menangani dalam hal proses administrasi perjalanan dinas di Biro Umum. Website ini dapat memberikan informasi yang penting dalam hal biaya perjalanan dinas. Memberikan informasi mengenai sisa dana perjalanan dinas, grafik perjalanan dinas bulanan serta informasi pagu perjalanan dinas di Biro Umum.

\section{SARAN}

Diharapkan dikegiatan berikutnya dapat mengembangkan dalam bentuk tampilan, pembuatan laporan dan pemberian informasi yang lebih detail dan dapat mengembangkan membuat aplikasi yang terhubung langsung ke database pada bendahara pengeluaran dalam hal pembayaran perjalanan dinas.

\section{DAFTAR PUSTAKA}

Basrie, B., \& Yusnita, A. 2018. Membangun Sistem Infromasi E-learning Perkuliahan STMIK Wicida Samarinda. Sebatik, 20(1), 10-14.

Heryanto, Y. 2014. Implementasi Good Governance Terhadap Peningkatan Pelayanan Publik di Indonesia. Jurnal Logika, 12(3), 23-40.

Jogiyanto, H. M. 2017. Analisis dan Desain (Sistem Informasi Pendekatan Terstruktur Teori dan Praktek Aplikasi Bisnis). Penerbit Andi.

Kusnandar, K. 2016. Rancang Bangun \& Analisis Sistem Sistem Informasi Perpustakaan Menggunakan Model Waterfall (Studi Kasus: STMIK WICIDA Samarinda). Sebatik, 16(1), 16-25.

Nugroho, A. 2009. rekayasa perangkat lunak menggunakan UML dan JAVA. Penerbit Andi.

Sutabri, T. 2012. Konsep Sistem Informasi. Penerbit Andi.

Yuniarto, B. 2013. Membangun Kesadaran Warga Negara dalam Pelestarian Lingkungan. Deepublish. 